[Chem. Pharm. Bull.

32(10)3912-3917(1984)]

\title{
Studies on Sesquiterpenes from Macroclinidium trilobum MAKINO. I
}

\author{
Toshio Miyase, ${ }^{*}$ Katsuyuki Yamaki and Seigo Fukushima
}

Shizuoka College of Pharmacy, 2-2-1, Oshika, Shizuoka 422, Japan

(Received February 20, 1984)

\begin{abstract}
Five new sesquiterpene glycosides, macroclinisides A (II), B (III), C (IV), D (V), E (VI), have been isolated from Macroclinidium trilobum MAKINO together with glucozaluzanin $\mathrm{C}$ (I). The structures were determined on the basis of chemical and spectral data. Macrocliniside $\mathrm{C}$ has antitumor activity in mice.
\end{abstract}

Keywords_-Macroclinidium trilobum; Compositae; sesquiterpene glycoside; antitumor activity; macrocliniside $\mathrm{A}$; macrocliniside $\mathrm{B}$; macrocliniside $\mathrm{C}$; macrocliniside $\mathrm{D}$; macroliniside $\mathrm{E}$; glucozaluzanin $\mathrm{C}$

In connection with a study on the sesquiterpene glycosides of some plants in Compositae, we have also investigated Macroclinidium trilobum MAKINO (Syn. Pertya triloba MAKINO) and isolated five new guaianolide-type sesquiterpene glycosides, macroclinisides $\mathrm{A}-\mathrm{E}$, and glucozaluzanin $\mathrm{C}$ (a known compound). The structures of the five new glycosides were determined on the basis of some chemical transformations and spectroscopic studies using mainly carbon-13 nuclear magnetic resonance $\left({ }^{13} \mathrm{C}-\mathrm{NMR}\right)$ spectra.

Glucozaluzanin $\mathrm{C}(\mathrm{I}): \mathrm{C}_{21} \mathrm{H}_{28} \mathrm{O}_{8} \cdot \mathrm{H}_{2} \mathrm{O}, \mathrm{mp} 103-105^{\circ} \mathrm{C}$. The proton nuclear magnetic resonance $\left({ }^{1} \mathrm{H}-\mathrm{NMR}\right)$ spectrum exhibited doublets at $\delta 5.38(1 \mathrm{H}, J=3.3 \mathrm{~Hz})$ and $6.22(1 \mathrm{H}$, $J=3.3 \mathrm{~Hz}$ ), which are characteristic of exocyclic $\alpha$-methylene- $\gamma$-lactone. Acetylation of I afforded a tetraacetate (Ia), $\mathrm{C}_{29} \mathrm{H}_{36} \mathrm{O}_{12}, \mathrm{mp} 160-162^{\circ} \mathrm{C}$. From these results and the spectral data, I was assumed to be glucozaluzanin C, previously isolated from Ainsliae acerifolia $\mathrm{SCH}$. BIP. ${ }^{1)}$ The identity of I was established by direct comparison [thin layer chromatography (TLC), infrared (IR), ${ }^{1} \mathrm{H}-\mathrm{NMR}$, mixed $\mathrm{mp}$ ] with an authentic sample.

Macrocliniside A (II): $\mathrm{C}_{21} \mathrm{H}_{28} \mathrm{O}_{9} \cdot 1 / 2 \mathrm{H}_{2} \mathrm{O},[\alpha]_{\mathrm{D}}-8.8^{\circ}$. The field desorption mass spectrum (FD-MS) exhibited an ion peak at $m / z 447(\mathrm{M}+\mathrm{Na})^{+}$. The IR spectrum suggested the presence of hydroxyl groups $\left(3400 \mathrm{~cm}^{-1}\right)$, an unsaturated $\gamma$-lactone $\left(1750 \mathrm{~cm}^{-1}\right)$ and double bonds $\left(1660,1635 \mathrm{~cm}^{-1}\right)$. The ${ }^{1} \mathrm{H}-\mathrm{NMR}$ spectrum exhibited signals due to three exomethylene groups at $\delta 5.18(2 \mathrm{H}, \mathrm{s}), 5.48(1 \mathrm{H}, \mathrm{d}, J=3.1 \mathrm{~Hz}) ; 6.26(1 \mathrm{H}, \mathrm{d}, J=3.3 \mathrm{~Hz})$ and $5.56(1 \mathrm{H}$, brs $) ; 5.96(1 \mathrm{H}$, br s), suggesting that II had a guaianolide-type skeleton, like glucozaluzanin $\mathrm{C}(\mathrm{I})$. The ${ }^{13} \mathrm{C}-\mathrm{NMR}$ spectrum also indicated the presence of three exomethylene groups: $\delta 111.1,112.2,118.9$ (each triplet); 141.2, 150.9, 153.3 (each singlet). Acetylation of II afforded a pentaacetate (IIa), $\mathrm{C}_{31} \mathrm{H}_{38} \mathrm{O}_{14}, \mathrm{mp} 215-216.5^{\circ} \mathrm{C}$. Acid hydrolysis of II afforded glucose as the sugar moiety. In the ${ }^{13} \mathrm{C}-\mathrm{NMR}$ spectrum of II, various signals showed shifts as compared with those of $\mathrm{I}$ : C-1 and C-7 (each $\gamma$-position) at $\delta 41.6$ $(\Delta-3.3 \mathrm{ppm})$ and $37.0(\Delta-8.3 \mathrm{ppm})$, respectively, C-8 and C-10 (each $\beta$-position) at $\delta 39.8$ $(\Delta+9.1 \mathrm{ppm})$ and $153.3(\Delta+4.3 \mathrm{ppm})$, respectively, and C-9 $(\alpha$-position) at $\delta 72.3$ $(\Delta+38.1 \mathrm{ppm})$. Thus, Compound II was assumed to be a glucozaluzanin $\mathrm{C}$ analog having a hydroxyl group at C-9. The stereochemistry at C-9 was determined from the fact that II gave ixerin $\mathrm{F}$ (IIc) upon sodium borohydride reduction, ${ }^{2)}$ and the stereochemistry of the anomeric center was deduced from the $J_{\mathrm{C}_{1}-\mathrm{H}_{1}}$ coupling constant $(157 \mathrm{~Hz}) .{ }^{3)}$ These results led us to conclude the structure of macrocliniside $\mathrm{A}$ to be II. 


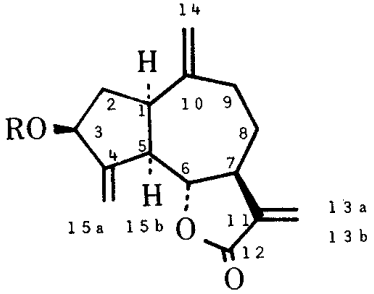

$\begin{aligned} \text { I : } & \mathbf{R}=\beta \text {-glc } \\ \text { Ia : } & \mathbf{R}=(\beta \text {-glc }) \mathrm{Ac}_{4} \\ \text { Ib : } & \mathbf{R}=\mathrm{H} \\ \text { III : } & \mathbf{R}=\beta \text {-glc } \frac{31}{1} \beta \text {-glc }\end{aligned}$<smiles>[R2]C1C[C@H]2C(=C)C([R2])C[C@@H]3C(=C)C(=O)O[C@@H]3[C@@H]2C1=C</smiles>

II : $\mathrm{R}=\mathrm{H}$,

IIa: $\quad \mathrm{R}=\mathrm{COCH}_{3}, \mathrm{R}^{\prime}=(\beta-\mathrm{glc}) \mathrm{Ac}_{4}$

IIb: $\mathrm{R}=\mathrm{H}$

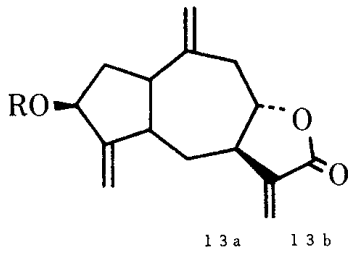

IV: $\mathrm{R}=\beta$-glc

IVa: $\quad \mathbf{R}=(\beta-\mathrm{glc}) \mathrm{Ac}_{4}$

$\mathrm{IVb}: \quad \mathrm{R}=\mathrm{H}$

$\mathrm{V}: \quad \mathrm{R}=\beta$-glc $\stackrel{31}{-} \beta$-glc

Va: $\quad \mathrm{R}=\left(\beta\right.$-glc $\frac{31}{1}-\beta$-glc $) \mathrm{Ac}_{7}$

$\mathrm{VI}: \quad \mathrm{R}=\beta$-glc $\frac{31}{1} \beta$-glc<smiles>[R20]C1C[C@H]2C(=C)[C@@H](O)C[C@@H]3[C@H](OC(=O)[C@@H]3C)[C@@H]2C1=C</smiles>

IIc : $\quad \mathrm{R}=\beta$-glc

Chart 1

TABLE I. ${ }^{1}$ H-NMR Chemical Shifts and Coupling Constants

\begin{tabular}{|c|c|c|c|}
\hline $\begin{array}{c}\text { Proton } \\
\text { No. }\end{array}$ & I & II & III \\
\hline $13 \mathbf{a}$ & $5.38(1 \mathrm{H}, \mathrm{d}, J=3.3 \mathrm{~Hz})$ & $5.48(1 \mathrm{H}, \mathrm{d}, J=3.1 \mathrm{~Hz})$ & $5.41(1 \mathrm{H}, \mathrm{d}, J=3.1 \mathrm{~Hz})$ \\
\hline $13 b$ & $6.22(1 \mathrm{H}, \mathrm{d}, J=3.3 \mathrm{~Hz})$ & $6.26(1 \mathrm{H}, \mathrm{d}, J=3.3 \mathrm{~Hz})$ & $6.23(1 \mathrm{H}, \mathrm{d}, J=3.2 \mathrm{~Hz})$ \\
\hline \multirow{2}{*}{14} & $4.85(1 \mathrm{H}, \mathrm{s})$ & \multirow{2}{*}{$5.18(2 \mathrm{H}, \mathrm{s})$} & $4.85(1 \mathrm{H}, \mathrm{s})$ \\
\hline & $5.02(1 \mathrm{H}, \mathrm{s})$ & & $5.00(1 \mathrm{H}, \mathrm{s})$ \\
\hline $15 \mathbf{a}$ & $5.85(1 \mathrm{H}$, brs $)$ & $5.96(1 \mathrm{H}$, br s $)$ & $5.83(1 \mathrm{H}$, br s $)$ \\
\hline $15 b$ & $5.53(1 \mathrm{H}$, br s $)$ & $5.56(1 \mathrm{H}$, br s $)$ & $5.53(1 \mathrm{H}, \mathrm{brs})$ \\
\hline $\begin{array}{c}\text { Proton } \\
\text { No. }\end{array}$ & IV & $\mathrm{V}$ & VI \\
\hline $13 \mathbf{a}$ & $5.44(1 \mathrm{H}, \mathrm{d}, J=3.1 \mathrm{~Hz})$ & $5.44(1 \mathrm{H}, \mathrm{d}, J=3.1 \mathrm{~Hz})$ & $5.47(1 \mathrm{H}, \mathrm{d}, J=3.1 \mathrm{~Hz})$ \\
\hline 13b & $6.20(1 \mathrm{H}, \mathrm{d}, J=3.4 \mathrm{~Hz})$ & $6.18(1 \mathrm{H}, \mathrm{d}, J=3.2 \mathrm{~Hz})$ & $6.23(1 \mathrm{H}, \mathrm{d}, J=3.2 \mathrm{~Hz})$ \\
\hline \multirow{2}{*}{14} & $4.92(1 \mathrm{H}, \mathrm{s})$ & $4.91(1 \mathrm{H}, \mathrm{s})$ & $4.94(1 \mathrm{H}, \mathrm{s})$ \\
\hline & $5.04^{a)}$ & $5.02^{a)}$ & $5.06^{a)}$ \\
\hline $15 a$ & $5.79(1 \mathrm{H}$, br s $)$ & $5.76(1 \mathrm{H}$, br s $)$ & $5.82(1 \mathrm{H}$, br s $)$ \\
\hline $15 b$ & $5.04^{a)}$ & $5.02^{a)}$ & $5.06^{a)}$ \\
\hline
\end{tabular}

Run at $89.55 \mathrm{MHz}$ in pyridine- $d_{5}$ solution.

a) Overlapped each other (in each column).

Macrocliniside B (III): $\mathrm{C}_{27} \mathrm{H}_{38} \mathrm{O}_{13} \cdot \mathrm{H}_{2} \mathrm{O},[\alpha]_{D}-18.3^{\circ}$. The FD-MS exhibited an ion peak at $\mathrm{m} / \mathrm{z} 593(\mathrm{M}+\mathrm{Na})^{+}$. The IR spectrum suggested the presence of hydroxyl groups $\left(3400 \mathrm{~cm}^{-1}\right)$, an unsaturated $\gamma$-lactone $\left(1760 \mathrm{~cm}^{-1}\right)$ and double bonds $\left(1660,1635 \mathrm{~cm}^{-1}\right)$. The ${ }^{1} \mathrm{H}$-NMR spectrum was similar to that of $\mathrm{I}$, exhibiting three exomethylene groups at $\delta 4.85$ $(1 \mathrm{H}, \mathrm{s}) ; 5.00(1 \mathrm{H}, \mathrm{s}), 5.41(1 \mathrm{H}, \mathrm{d}, J=3.1 \mathrm{~Hz}) ; 6.23(1 \mathrm{H}, \mathrm{d}, J=3.2 \mathrm{~Hz})$ and $5.53(1 \mathrm{H}, \mathrm{br} \mathrm{s}) ; 5.83$ $(1 \mathrm{H}$, brs $)$. Enzymatic hydrolysis of III afforded zaluzanin $\mathrm{C}(\mathrm{Ib})$ as aglycone, and acid hydrolysis afforded glucose as the sugar moiety. The ${ }^{13} \mathrm{C}-\mathrm{NMR}$ spectrum of III showed almost the same signals in the aglycone region as that of $\mathrm{I}$, but in the sugar region six more signals were observed. Therefore, III was assumed to be a diglucoside of zaluzanin $\mathrm{C}(\mathrm{Ib})$. The C-3' of glucose showed a downfield shift in the ${ }^{13} \mathrm{C}-\mathrm{NMR}$, at $\delta 88.7(\Delta+10.1 \mathrm{ppm})$, and the C$2^{\prime}$ and C-4' showed highfield shifts at $\delta 73.9(\Delta-1.5 \mathrm{ppm})$ and $69.9(\Delta-2.1 \mathrm{ppm})$, respectively. Thus, a glucose was attached to $\mathrm{C}-3^{\prime}$ of another glucose, so that the structure of 
TABLE II. ${ }^{13} \mathrm{C}-\mathrm{NMR}$ Chemical Shifts and Coupling Constants

\begin{tabular}{|c|c|c|c|c|c|c|}
\hline Carbon No. & I & II & III & IV & $\mathrm{V}$ & VI \\
\hline \multicolumn{7}{|l|}{ Aglycone moiety } \\
\hline 1 & $44.9^{a)}$ & 41.6 & $44.8^{b)}$ & $45.1^{c)}$ & $45.2^{d)}$ & $45.2^{e)}$ \\
\hline 2 & 38.2 & 37.5 & 38.0 & 37.5 & 37.4 & 37.6 \\
\hline 3 & 80.6 & 80.8 & 80.5 & 80.3 & 80.4 & 80.6 \\
\hline 4 & 150.6 & 150.9 & 150.2 & 153.4 & 154.2 & 154.4 \\
\hline 5 & 50.4 & 49.5 & 50.3 & 47.6 & 47.7 & 47.7 \\
\hline 6 & 83.7 & 84.4 & 83.5 & 28.6 & 28.6 & 28.7 \\
\hline 7 & $45.3^{a)}$ & 37.0 & $45.3^{b)}$ & $44.8^{c)}$ & $44.8^{d)}$ & $44.9^{e)}$ \\
\hline 8 & 30.7 & 39.8 & 30.7 & 85.0 & 84.9 & 85.0 \\
\hline 9 & 34.2 & 72.3 & 34.1 & 42.3 & 42.4 & 42.4 \\
\hline 10 & 149.0 & 153.3 & 148.8 & 144.4 & 144.4 & 144.5 \\
\hline 11 & 141.1 & 141.2 & 140.9 & 140.7 & 140.8 & 140.8 \\
\hline 12 & 170.0 & 170.1 & 169.8 & 170.0 & 170.0 & 170.1 \\
\hline 13 & 119.4 & 118.9 & 119.4 & 118.1 & 118.0 & 118.0 \\
\hline 14 & 114.0 & 111.1 & 114.0 & 116.4 & 116.4 & 116.5 \\
\hline 15 & 112.5 & 112.2 & 112.5 & 107.7 & 107.7 & 107.8 \\
\hline \multicolumn{7}{|l|}{ Sugar moiety } \\
\hline $1^{\prime}$ & 104.1 & $104.4(157 \mathrm{~Hz})$ & $103.5(157 \mathrm{~Hz})$ & $104.8(156 \mathrm{~Hz})$ & $104.4(156 \mathrm{~Hz})$ & $104.7(155 \mathrm{~Hz})^{f)}$ \\
\hline $2^{\prime}$ & 75.4 & 75.3 & 73.9 & 75.1 & 73.9 & 74.8 \\
\hline $3^{\prime}$ & 78.6 & 78.6 & 88.7 & 78.5 & 88.9 & 76.4 \\
\hline $4^{\prime}$ & 72.0 & 71.9 & 69.9 & 71.7 & 69.8 & 81.4 \\
\hline $5^{\prime}$ & 78.3 & 78.2 & 77.7 & 78.1 & 77.9 & 76.8 \\
\hline $6^{\prime}$ & 63.1 & 63.0 & 62.5 & 62.9 & 62.5 & 62.5 \\
\hline $1^{\prime \prime}$ & & & $105.7(159 \mathrm{~Hz})$ & & $105.9(160 \mathrm{~Hz})$ & $104.9(158 \mathrm{~Hz})^{f)}$ \\
\hline $2^{\prime \prime}$ & & & 75.4 & & 75.4 & 74.8 \\
\hline $3^{\prime \prime}$ & & & 78.4 & & 78.5 & $78.3^{g)}$ \\
\hline $4^{\prime \prime}$ & & & 71.6 & & 71.6 & 71.6 \\
\hline $5^{\prime \prime}$ & & & 78.0 & & 78.1 & $78.2^{g)}$ \\
\hline $6^{\prime \prime}$ & & & 62.5 & & 62.5 & 62.5 \\
\hline
\end{tabular}

Run at $22.5 \mathrm{MHz}$ in pyridine- $d_{5}$ solution.

$a-g)$ Assignments may be interchanged in each column.

macrocliniside $\mathrm{B}$ is III. ${ }^{4)}$ The stereochemistry of the two anomeric centers was deduced to be $\beta$ from the $J_{\mathrm{C}_{1}-\mathrm{H}_{1}}$ coupling constants $(157,159 \mathrm{~Hz}){ }^{3)}$

Macrocliniside $\mathrm{C}$ (IV): $\mathrm{C}_{21} \mathrm{H}_{28} \mathrm{O}_{8} \cdot 1 / 2 \mathrm{H}_{2} \mathrm{O},[\alpha]_{D}+13.6^{\circ}$. The FD-MS exhibited an ion peak at $m / z 409(\mathrm{M}+1)^{+}$. The IR spectrum suggested the presence of hydroxyl groups $\left(3420 \mathrm{~cm}^{-1}\right)$, an unsaturated $\gamma$-lactone $\left(1762 \mathrm{~cm}^{-1}\right)$ and double bonds $\left(1660,1635 \mathrm{~cm}^{-1}\right)$. The ${ }^{1} \mathrm{H}-\mathrm{NMR}$ spectrum showed doublets at $\delta 5.44(1 \mathrm{H}, \mathrm{d}, J=3.1 \mathrm{~Hz})$ and $6.20(1 \mathrm{H}, \mathrm{d}, J=3.4 \mathrm{~Hz})$, which were characteristic of exocyclic $\alpha$-methylene- $\gamma$-lactone. The allylic coupling constants were both larger than $3.0 \mathrm{~Hz}$, so the $\gamma$-lactone ring was suggested to be trans-fused. ${ }^{5}$ Furthermore, two exomethylene groups were observed at $\delta 4.92(1 \mathrm{H}, \mathrm{s}) ; 5.04$ (overlapped) and 5.04 (overlapped); $5.79\left(1 \mathrm{H}\right.$, br s). Acetylation of IV afforded a tetraacetate (IVa) $\mathrm{C}_{29} \mathrm{H}_{36} \mathrm{O}_{12}$, $\mathrm{mp} 162-163^{\circ} \mathrm{C}$. Acid hydrolysis of IV gave glucose as the sugar moiety and enzymatic hydrolysis gave an unstable aglycone (IVb). The MS of IVb showed a molecular ion peak at $m / z 246$ in agreement with the molecular formula $\mathrm{C}_{15} \mathrm{H}_{18} \mathrm{O}_{3}$. The ${ }^{1} \mathrm{H}-\mathrm{NMR}$ spectrum established IVb as a sesquiterpene lactone ${ }^{6)}$ exhibiting a carbinol proton signal at $\delta 4.56(1 \mathrm{H}$, $\mathrm{tt}, J=2.5,9.5 \mathrm{~Hz}$ ) which was long-range-coupled with two olefinic protons at $\delta 4.98$ and 5.20 (C-15 methylene protons), and a lactonized carbinol proton signal at $\delta 3.75(1 \mathrm{H}$, ddd, $J=5$, $12,13 \mathrm{~Hz})$. The circular dichroism $(\mathrm{CD})$ spectrum of IV showed a positive Cotton effect $[\theta]_{268}$ +169 , suggesting that the $\gamma$-lactone ring fusion is $7 \beta, 8 \alpha$-trans. ${ }^{7)}$ The ${ }^{13} \mathrm{C}-\mathrm{NMR}$ spectrum of IV 
supported the presence of a 7,8-lactone ring; C-9 ( $\beta$-position) was downfield shifted at $\delta 42.3$ $(\Delta+8.1 \mathrm{ppm})$ and $\mathrm{C}-10(\gamma$-position) was highfield shifted at $\delta 144.4(\Delta-4.6 \mathrm{ppm})$ as compared with the signals of a 6,7-lactonized guaianolide, glucozaluzanin C (I). Thus, IVb was assumed to be a 7,8-trans-lactonized guaianolide having a hydroxyl group at C-3. The stereochemistry at C-3 was established to be $S$ by Horeau's method. ${ }^{8)}$ If the assumption is made that the absolute configuration of the $\mathrm{C}-7$ side chain is as shown (as in all other known sesquiterpene lactones of authenticated stereochemistry), the structure of macrocliniside $\mathrm{C}$ can be concluded to be IV.

Macrocliniside D (V): $\mathrm{C}_{27} \mathrm{H}_{38} \mathrm{O}_{13}, \mathrm{mp} 238-241^{\circ} \mathrm{C},[\alpha]_{\mathrm{D}}-4.9^{\circ}$. The FD-MS exhibited an ion peak at $m / z 593(\mathrm{M}+\mathrm{Na})^{+}$. The ${ }^{1} \mathrm{H}-\mathrm{NMR}$ spectrum was very similar to that of IV and exhibited two olefinic proton signals due to exocyclic $\alpha$-methylene- $\gamma$-lactone at $\delta 5.44(1 \mathrm{H}$, d, $J=3.1 \mathrm{~Hz})$ and $6.18(1 \mathrm{H}, \mathrm{d}, J=3.2 \mathrm{~Hz})$ and two exomethylene signals at $\delta 4.91(1 \mathrm{H}, \mathrm{s}) ; 5.02$ (overlapped) and 5.02 (overlapped); $5.76(1 \mathrm{H}$, br s). Acetylation of $\mathrm{V}$ gave a heptaacetate (Va), $\mathrm{C}_{41} \mathrm{H}_{52} \mathrm{O}_{20}, \mathrm{mp} 181-185^{\circ} \mathrm{C}$. Enzymatic hydrolysis of $\mathrm{V}$ afforded $\mathrm{IVb}$ as an aglycone and acid hydrolysis afforded glucose as the sugar moiety. The ${ }^{13} \mathrm{C}$-NMR spectrum of $\mathrm{V}$ showed almost the same signals in the aglycone region as that of IV, but in the sugar region six more signals were observed to be nearly superimposable on those of III. These results led us to conclude the structure of macrocliniside $\mathrm{D}$ to be $\mathrm{V}$.

Macrocliniside E (VI): $\mathrm{C}_{27} \mathrm{H}_{38} \mathrm{O}_{13},[\alpha]_{\mathrm{D}}+25.7^{\circ}$. The FD-MS exhibited an ion peak at $m / z 571(\mathrm{M}+1)^{+}$. The IR and ${ }^{1} \mathrm{H}-\mathrm{NMR}$ spectra were similar to those of $\mathrm{V}$ and the ${ }^{13} \mathrm{C}$-NMR spectrum suggested that VI was also a diglucoside of IVb. In the sugar region, C-4' of glucose was found to be shifted downfield to $\delta 81.4(\Delta+9.7 \mathrm{ppm})$ and $\mathrm{C}-3^{\prime}$ and $\mathrm{C}-5^{\prime}$ to be shifted highfield to $\delta 76.4(\Delta-2.1 \mathrm{ppm})$ and $76.8(\Delta-1.3 \mathrm{ppm})$, respectively, suggesting that a glucose is attached to $\mathrm{C}-4^{\prime}$ of another glucose. The stereochemistry of the two anomeric centers was shown to be both $\beta$ by the $J_{\mathrm{C}_{1}-\mathrm{H}_{1}}$ coupling constants $(155,158 \mathrm{~Hz}){ }^{3)}$ From these results, the structure of macrocliniside $\mathrm{E}$ was concluded to be VI.

Macroclinisides B, D and $\mathrm{E}$ are the first reported examples of diglycosides of a guaianolide-type sesquiterpene. Macrocliniside C (IV) was active in the sarcoma $180 \mathrm{Std}$ : ddY mice survival system at $150 \mathrm{mg} / \mathrm{kg} / \mathrm{d}(T / C>300 \%)$.

\section{Experimental}

Melting points were determined on a Yanaco MP-500 micromelting point apparatus and are uncorrected. Optical rotations were determined with a JASCO DIP-140 digital polarimeter. IR spectra were run on a JASCO A202 IR spectrophotometer, while MS were measured on a JEOL JMS-D 100 and FD-MS on a JEOL JMS-D 300 mass spectrometer. CD spectra were recorded on a JASCO J-40 spectropolarometer. ${ }^{1} \mathrm{H}-\mathrm{NMR}$ and ${ }^{13} \mathrm{C}-\mathrm{NMR}$ spectra were recorded on a JEOL FX-90Q NMR spectrometer $(89.55$ and $22.5 \mathrm{~Hz}$, respectively). Chemical shifts are given on a $\delta$ scale with tetramethylsilane as an internal standard (s, singlet; d, double; $t$, triplet; m, multiplet; br, broad). Gas chromatography (GC) was done on a Hitachi K 53 gas chromatograph. High performance liquid chromatography (HPLC) was done on a Kyowa Seimitsu model K 880 instrument.

Isolation-Air-dried whole herb of $M$. trilobum $(5 \mathrm{~kg})$ was extracted twice with methanol under reflux. The extract was concentrated under reduced pressure and the residue was suspended in water. This suspension was extracted with ether and $n$-butanol, successively. After repeated chromatography of the $n$-butanol-soluble fraction $(120 \mathrm{~g})$ using a chloroform-methanol system with Silica gel 60 and a water-acetonitrile system with silanized silica gel, six sesquiterpene glycosides were isolated.

Glucozaluzanin C (I)-Recrystallization from water gave colorless needles $(0.3 \mathrm{~g}), \mathrm{mp} 103-105^{\circ} \mathrm{C}$. Anal. Calcd for $\mathrm{C}_{21} \mathrm{H}_{28} \mathrm{O}_{8} \cdot \mathrm{H}_{2} \mathrm{O}: \mathrm{C}, 59.14 ; \mathrm{H}, 7.09$. Found: C, 59.28; $\mathrm{H}, 6.86$. IR $v_{\max }^{\mathrm{KBr}} \mathrm{cm}^{-1}: 3400,1755,1660,1635 .{ }^{1} \mathrm{H}-$ NMR and ${ }^{13} \mathrm{C}-\mathrm{NMR} \delta$ : Table I, II. This was identified by direct comparison (mixed $\mathrm{mp}, \mathrm{IR},{ }^{1} \mathrm{H}-\mathrm{NMR}$, TLC) with an authentic sample.

Macrocliniside A (II)_-Amorphous powder $(0.1 \mathrm{~g}) .[\alpha]_{\mathrm{D}}^{24}-8.8^{\circ}(c=1.14$, methanol). Anal. Calcd for $\mathrm{C}_{21} \mathrm{H}_{28} \mathrm{O}_{9} \cdot 1 / 2 \mathrm{H}_{2} \mathrm{O}: \mathrm{C}, 58.19 ; \mathrm{H}, 6.74$. Found: C, 57.92; H, 6.70. IR $v_{\max }^{\mathrm{KBr}} \mathrm{cm}^{-1}: 3400,1750,1660,1635$. FD-MS $m / z$ : $447(\mathrm{M}+\mathrm{Na})^{+} .{ }^{1} \mathrm{H}-\mathrm{NMR}$ and ${ }^{13} \mathrm{C}-\mathrm{NMR} \delta$ : Tables I, II.

Macrocliniside B (III)-Amorphous powder $(0.2 \mathrm{~g}) .[\alpha]_{\mathrm{D}}^{25}-18.3^{\circ}(c=1.15$, water). FD-MS $m / z: 593$ 
$(\mathrm{M}+\mathrm{Na})^{+}$. Anal. Calcd for $\mathrm{C}_{27} \mathrm{H}_{38} \mathrm{O}_{13} \cdot \mathrm{H}_{2} \mathrm{O}: \mathrm{C}, 55.09 ; \mathrm{H}, 6.85$. Found: C, 55.14; H, 6.69. IR $v_{\max }^{\mathrm{KBr}} \mathrm{cm}^{-1}: 3400,1760$, 1660, 1635. ${ }^{1} \mathrm{H}-\mathrm{NMR}$ and ${ }^{13} \mathrm{C}-\mathrm{NMR} \delta$ : Tables I, II.

Macrocliniside C (IV)-Amorphous powder $(10 \mathrm{~g}) .[\alpha]_{\mathrm{D}}^{25}+13.6^{\circ}(c=1.10$, water). Anal. Calcd for $\mathrm{C}_{21} \mathrm{H}_{28} \mathrm{O}_{8} \cdot 1 / 2 \mathrm{H}_{2} \mathrm{O}: \mathrm{C}, 60.42 ; \mathrm{H}, 7.00$. Found: C, 60.31; H, 7.00. IR $v_{\max }^{\mathrm{KBr}} \mathrm{cm}^{-1}: 3420,1762,1660,1635$. FD-MS $m / z$ : $409(\mathrm{M}+1)^{+}$. CD $\left(c=0.48\right.$, methanol) $[\theta](\mathrm{nm}):+169(268) .{ }^{1} \mathrm{H}-\mathrm{NMR}$ and ${ }^{13} \mathrm{C}-\mathrm{NMR} \delta$ : Tables I, II.

Macrocliniside D (V)—-Recrystallization from methanol gave colorless needles $(1 \mathrm{~g}), \mathrm{mp} 238-241^{\circ} \mathrm{C}$. $[\alpha]_{\mathrm{D}}^{25}$ $-4.9^{\circ}\left(c=0.41\right.$, water). Anal. Calcd for $\mathrm{C}_{27} \mathrm{H}_{38} \mathrm{O}_{13}: \mathrm{C}, 56.83 ; \mathrm{H}, 6.71$. Found: C, 56.68; $\mathrm{H}, 6.68$. IR $v_{\max }^{\mathrm{KBr}} \mathrm{cm}^{-1}: 3350$, $1758,1660,1635$. FD-MS $m / z: 593(\mathrm{M}+\mathrm{Na})^{+} . \mathrm{CD}(c=0.33$, water $)[\theta](\mathrm{nm}):+170(266) .{ }^{1} \mathrm{H}-\mathrm{NMR}$ and ${ }^{13} \mathrm{C}-\mathrm{NMR}$ $\delta$ : Tables I, II.

Macrocliniside E (VI)-Amorphous powder $(0.1 \mathrm{~g})$. $[\alpha]_{\mathrm{D}}^{25}+25.7^{\circ}(c=0.53$, water). Anal. Calcd for $\mathrm{C}_{27} \mathrm{H}_{38} \mathrm{O}_{13} \cdot \mathrm{H}_{2} \mathrm{O}: \mathrm{C}, 55.09 ; \mathrm{H}, 6.85$. Found: C, 54.86; H, 6.67. IR $v_{\max }^{\mathrm{KBr}} \mathrm{cm}^{-1}: 3420,1760,1660,1630$. FD-MS $m / z: 571$ $(\mathrm{M}+1)^{+} . \mathrm{CD}\left(c=0.20\right.$, water $[\theta](\mathrm{nm}):+88(263) .{ }^{1} \mathrm{H}-\mathrm{NMR}$ and ${ }^{13} \mathrm{C}-\mathrm{NMR} \delta:$ Tables I, II.

Acetylation of Glucozaluzanin C (I), and Macroclinisides A (II), C (IV) and D (V)—I (30 mg), II (25 mg), IV $(15 \mathrm{mg})$ and $\mathrm{V}(66 \mathrm{mg})$ were acetylated in the usual manner using acetic anhydride and pyridine to give the acetate Ia (20 mg), IIa (15 mg), IVa (10 mg) and Va (40 mg), respectively. Ia: Colorless needles, $\mathrm{mp} 160-162{ }^{\circ} \mathrm{C}$ (methanol). ${ }^{1} \mathrm{H}-$ NMR $\left(\mathrm{CDCl}_{3}\right) \delta: 1.97,2.00,2.04,2.10(3 \mathrm{H} \mathrm{each}, \mathrm{s}, \mathrm{OAc}), 4.54(1 \mathrm{H}, \mathrm{br} \mathrm{t}, J=6 \mathrm{~Hz}, \mathrm{H}-3), 5.47(1 \mathrm{H}, \mathrm{d}, J=3.3 \mathrm{~Hz}, \mathrm{H}-$ 13a), $6.17(1 \mathrm{H}, \mathrm{d}, J=3.3 \mathrm{~Hz}, \mathrm{H}-13 \mathrm{~b})$. This was identified by direct comparison (mixed mp, $\left.{ }^{1} \mathrm{H}-\mathrm{NMR}\right)$ with an authentic sample. ${ }^{1)}$ Ila: Colorless needles, mp $215-216.5^{\circ} \mathrm{C}$ (chloroform-methanol). ${ }^{1} \mathrm{H}-\mathrm{NMR}\left(\mathrm{CDCl}_{3}\right) \delta: 1 . \varsigma 6$, $1.99,2.03,2.09,2.10\left(3 \mathrm{H}\right.$ each, s, OAc), $6.23(1 \mathrm{H}, \mathrm{d}, J=3.5 \mathrm{~Hz}, \mathrm{H}-13 \mathrm{~b})$. IVa: Colorless needles, $\mathrm{mp} 162-163^{\circ} \mathrm{C}$ (methanol). Anal. Calcd for $\mathrm{C}_{29} \mathrm{H}_{36} \mathrm{O}_{12}: \mathrm{C}, 60.41 ; \mathrm{H}, 6.29$. Found: $\mathrm{C}, 60.41 ; \mathrm{H}, 6.18 .{ }^{1} \mathrm{H}-\mathrm{NMR}\left(\mathrm{CDCl}_{3}\right) \delta: 2.02,2.03$, 2.04, 2.07 (3H each, s, OAc), $3.75(1 \mathrm{H}, \mathrm{m}, \mathrm{H}-8), 4.46(1 \mathrm{H}$, br t $, J=7 \mathrm{~Hz}, \mathrm{H}-3), 5.47(1 \mathrm{H}, \mathrm{d}, J=3.2 \mathrm{~Hz}, \mathrm{H}-13 \mathrm{a}), 6.17$ $(1 \mathrm{H}, \mathrm{d}, J=3.5 \mathrm{~Hz}, \mathrm{H}-13 \mathrm{~b})$. Va: Colorless needles, $\mathrm{mp} 181-185^{\circ} \mathrm{C}$ (ethyl acetate-hexane). Anal. Calcd for $\mathrm{C}_{41} \mathrm{H}_{52} \mathrm{O}_{20}$ : $\mathrm{C}, 56.94 ; \mathrm{H}, 6.06$. Found: $\mathrm{C}, 56.66 ; \mathrm{H}, 6.00 .{ }^{1} \mathrm{H}-\mathrm{NMR}\left(\mathrm{CDCl}_{3}\right) \delta: 1.99,2.04,2.12(3 \mathrm{H}$ each, s, OAc), $2.02,2.08(6 \mathrm{H}$ each, s, OAc $\times 2), 5.17(1 \mathrm{H}, \mathrm{d}, J=3.1 \mathrm{~Hz}, \mathrm{H}-13 \mathrm{a}), 6.17(1 \mathrm{H}, \mathrm{d}, J=3.3 \mathrm{~Hz}, \mathrm{H}-13 \mathrm{~b})$.

Acid Hydrolysis of Macroclinisides A (II), B (III), C (IV), D (V) and E (VI)-A solution of a glycoside (ca. $1 \mathrm{mg}$ ) in $10 \%$ sulfuric acid $(1 \mathrm{ml})$ was heated in a boiling water bath for $20 \mathrm{~min}$. The solution was passed through an Amberlite IRA-45 column and concentrated to give a residue, which was reduced with sodium borohydride ( $c a$. $2 \mathrm{mg}$ ) for $1 \mathrm{~h}$ at room temperature. The reaction mixture was passed through an Amberlite IR-120 column and the eluate was concentrated to dryness. Boric acid was removed by codistillation with methanol and the residue was acetylated with acetic anhydride and pyridine ( 1 drop each) at $100^{\circ} \mathrm{C}$ for $1 \mathrm{~h}$. The reagents were evaporated off in vacuo. From each glycoside, glucitol acetate was detected by GC. Conditions: column, 1.5\% OV-17, $3 \mathrm{~mm} \times$ $1 \mathrm{~m}$; column temperature, $230^{\circ} \mathrm{C}$; carrier gas, $\mathrm{N}_{2} ; t_{\mathrm{R}} 3.7 \mathrm{~min}$.

Enzymatic Hydrolysis of Macroclinisides A (II), B (III), C (IV), D (V) and E (VI)—A glycoside ( ca. $1 \mathrm{mg}$ ) was dissolved in water $(0.2 \mathrm{ml})$, crude hesperidinase $(c a .1 \mathrm{mg})$ was added to the solution, and the reaction mixture was stirred for $1 \mathrm{~h}$ at $37^{\circ} \mathrm{C}$. The aglycone was extracted with ethyl acetate and detected by HPLC. Conditions: column, Lichrosorb RP-8, $4 \mathrm{~mm} \times 25 \mathrm{~cm}$; solvent, methanol-water $(6: 4)$; flow, $1.2 \mathrm{ml} / \mathrm{min}$; detector, UV $220 \mathrm{~nm} ; t_{\mathrm{R}} 3.2 \mathrm{~min}$ (IIb from II), $4.7 \mathrm{~min}$ (IVb from IV, $\mathrm{V}$ and. $\mathrm{VI}$ ), $5.3 \mathrm{~min}$ (Ib from III).

Sodium Borohydride Reduction of Macrocliniside A (II)—A solution of macrocliniside A (II) (11 mg) in methanol $(1 \mathrm{ml})$ was treated at $0{ }^{\circ} \mathrm{C}$ with sodium borohydride $(10 \mathrm{mg})$ and the mixture was stirred for $10 \mathrm{~min}$. The reaction mixture was acidified with acetic acid, diluted with water and then passed through an Amberlite XAD-2 column. The column was washed with water and the reaction product was eluted with methanol. Purification on a silica gel column using ethyl acetate-methanol-water $(95: 5: 1.5)$ as the eluent, provided an amorphous powder. IR $v_{\max }^{\mathrm{KBr}} \mathrm{cm}^{-1}: 3400,1755,1655,1635 .{ }^{1} \mathrm{H}-\mathrm{NMR}$ (pyridine- $\left.d_{5}\right) \delta 1.19\left(3 \mathrm{H}, \mathrm{d}, J=7 \mathrm{~Hz}, \mathrm{CH}_{3}\right), 2.91(1 \mathrm{H}, \mathrm{br} \mathrm{t}, J=9 \mathrm{~Hz}, \mathrm{H}-5)$, $5.08\left(2 \mathrm{H}, \mathrm{s}, \mathrm{CH}_{2}\right.$ of C-14), $5.47\left(1 \mathrm{H}\right.$, br s, H-15a), 5.90 (1H, br s, H-15b). ${ }^{13} \mathrm{C}-\mathrm{NMR}$ (pyridine- $\left.d_{5}\right) \delta: 13.3(\mathrm{C}-13), 36.7$ (C-7), 37.5 (C-2), 40.9 (C-8), 42.0 (C-1), 45.5 (C-11), 49.5 (C-5), 63.1 (C-6'), 72.0 (C-4'), 73.1 (C-9), 75.4 (C-2'), 78.2 $\left(\mathrm{C}-5^{\prime}\right), 78.6\left(\mathrm{C}-3^{\prime}\right), 80.8(\mathrm{C}-3), 84.0(\mathrm{C}-6), 104.5\left(\mathrm{C}-1^{\prime}\right), 111.1(\mathrm{C}-14), 111.6(\mathrm{C}-15), 151.4(\mathrm{C}-4), 153.7$ (C-10), $178.5(\mathrm{C}-$ 12). This was identified as ixerin $F$ by direct comparison (TLC, IR, ${ }^{1} \mathrm{H}-\mathrm{NMR},{ }^{13} \mathrm{C}-\mathrm{NMR}$ ) with an authentic sample.

Enzymatic Hydrolysis of Macrocliniside C (IV)_A solution of macrocliniside C (IV) $(240 \mathrm{mg})$ in water ( $5 \mathrm{ml})$ was treated with crude hesperidinase $(170 \mathrm{mg})$ at $37^{\circ} \mathrm{C}$ overnight. The reaction mixture was extracted with ethyl acetate. The ethyl acetate extract was concentrated to give a residue, which yielded an unstable aglycone (IVb) (90 mg), mp $128-131^{\circ} \mathrm{C}$ from methanol. MS m/z: $246\left(\mathrm{M}^{+}, 5\right), 228\left(\mathrm{M}^{+}-\mathrm{H}_{2} \mathrm{O}, 23\right), 202(27), 188(23), 109(5), 105$ (52), $91(100) .{ }^{1} \mathrm{H}-\mathrm{NMR}\left(\mathrm{CDCl}_{3}\right) \delta: 3.05(1 \mathrm{H}, \mathrm{dd}, J=5,13 \mathrm{~Hz}, \mathrm{H}-9), 3.75(1 \mathrm{H}, \mathrm{ddd}, J=5,12,13 \mathrm{~Hz}, \mathrm{H}-8), 4.56(1 \mathrm{H}$, $\mathrm{tt}, J=2.5,9.5 \mathrm{~Hz}, \mathrm{H}-3), 4.98(1 \mathrm{H}, \mathrm{t}, J=2.5 \mathrm{~Hz}, \mathrm{H}-15 \mathrm{~b}), 5.07\left(2 \mathrm{H}, \mathrm{s}, \mathrm{CH}_{2}\right.$ of C-14), $5.20(1 \mathrm{H}, \mathrm{t}, J=2.5 \mathrm{~Hz}, \mathrm{H}-15 \mathrm{a}), 5.49$ $(1 \mathrm{H}, \mathrm{d}, J=3.7 \mathrm{~Hz}, \mathrm{H}-13 \mathrm{a}), 6.17(1 \mathrm{H}, \mathrm{d}, J=4.1 \mathrm{~Hz}, \mathrm{H}-13 \mathrm{~b}) .{ }^{13} \mathrm{C}-\mathrm{NMR}$ (pyridine- $\left.d_{5}\right) \delta: 28.4(\mathrm{C}-6), 30.9(\mathrm{C}-2), 42.6(\mathrm{C}-$ 9), 44.4 (C-7), 45.2 (C-5), 48.3 (C-1), 72.6 (C-3), 85.4 (C-8), 105.3 (C-15), 116.3 (C-14), 118.0 (C-13), 140.8 (C-11), 144.8 (C-10), 158.4 (C-4), 170.2 (C-12).

Determination of the Configuration at $\mathbf{C}-3$ of IVb by Horeau's Method ${ }^{8)}$ _-Racemic $\alpha$-phenylbutylic anhydride $(210 \mathrm{mg}, 0.677 \mathrm{mmol})$ and $\mathrm{IVb}(85.6 \mathrm{mg}, 0.348 \mathrm{mmol})$ were dissolved in pyridine $(1 \mathrm{ml})$. The solution was allowed to stand at room temperature overnight, then water was added to hydrolyze the excess anhydride. The aqueous solution was extracted 4 times with ethyl acetate. The ethyl acetate layer was extracted with $5 \%$ sodium bicarbonate solution, 
washed with water and finally acidified with $3 \mathrm{~N}$ hydrogen chloride. The ethyl acetate solution was washed with water and dried over sodium sulfate and then concentrated in vacuo to a constant-weight residue, $122.3 \mathrm{mg}$. The ${ }^{1} \mathrm{H}-\mathrm{NMR}$ spectrum of the residue indicated that $\mathrm{IVb}$ was totally esterified. The sodium bicarbonate extract obtained above was extracted with chloroform before being acidified with hydrogen chloride. A chloroform extract of the acidic solution, worked up in the usual manner, yielded a residue which was dried to constant-weight, yielding $123.0 \mathrm{mg}$ of pure $\alpha$ phenylbutyric acid. The purity was established by ${ }^{1} \mathrm{H}-\mathrm{NMR}$ spectroscopy. The specific rotation of the acid was determined: $[\alpha]_{\mathrm{D}}^{24}-9.6^{\circ}$. The optical yield was $29 \%$. From this result, the configuration at $\mathrm{C}-3$ of IVb was deduced to be $S$.

Ackmowledgement We are indebted to Dr. G. Kusano, Tohoku University, for providing the plant materials, to Dr. Y. Sakamoto, Hiroshima Prefectural Institute of Public Health, for measurement of FD-MS, to Dr. M. Uchida for measurement of MS, and to Mrs. H. Kitamura for elemental analyses. We also thank the Instrument Center, Institute for Molecular Science, for the use of a CD spectrometer.

\section{References and Notes}

1) T. Miyase and S. Fukushima, Chem. Pharm. Bull., 32, 3043 (1984).

2) H. Asada, T. Miyase and S. Fukushima, Chem. Pharm. Bull., 32, 3036 (1984).

3) K. Bock, I. Lundt and C. Pedersen, Tetrahedron Lett., 1973, 1037.

4) H. Ishii, K. Tori, T. Tozyo and Y. Yoshimura, Chem. Pharm. Bull., 26, 671 (1978).

5) Z. Samek, Tetrahedron Lett., 1970, 671.

6) H. Yoshioka, T. J. Mabry and B. N. Timmerman, "Sesquiterpene Lactones," University of Tokyo Press, Tokyo, 1973.

7) W. Stöcklin, T. G. Waddell and T. A. Geissman, Tetrahedron, 26, 2397 (1970).

8) T. J. Mabry, W. Renold, H. E. Miller and H. B. Kagan, J. Org. Chem., 31, 681 (1966). 